\title{
Antihepatotoxic Effect of Feronia Limonia Fruit against Carbon Tetrachloride Induced Hepatic Damage in Albino Rats
}

\author{
Rucha Upadhyay ${ }^{1}$, Narendra Deo Pandey ${ }^{1}$, Shahid Suhail Narvi ${ }^{1}$, Amita Verma ${ }^{2}$, Bahar Ahmed ${ }^{2}$ \\ ${ }^{1}$ Department of Chemistry Motilal Nehru National Institute of Technology, Allahabad, India \\ ${ }^{2}$ Department of Pharmaceutical Chemistry, Faculty of Pharmacy, Hamdard University, New Delh, India \\ E-mail: rucha.upadhyay@gmail.com \\ Received March 10, 2010; revised April 28, 2010; accepted May 10, 2010
}

\begin{abstract}
Feronia limonia Swingle, though mentioned as a high utility medicinal plant in Ayurveda for the treatment of liver disorders, but has no scientific investigations. Therefore, the present study was undertaken to investigate the hepatoprotective activity of extracts of Feronia limonia fruit on albino rat liver, damage induced by single dose of carbon-tetrachloride $(1.5 \mathrm{ml} / \mathrm{kg}$, p.o.). The oral administration of extracts $(500 \mathrm{mg} / \mathrm{kg}$, p.o. $)$ for 7 days has shown significant hepatoprotective action. There is reduction in the elevated levels of serum enzymes such SGOT, SGPT, ALP and Serum bilirubin and elevation in level of GSH, GPX,GLY and total protein in Feronia limonia protected rats.
\end{abstract}

Keywords: Anti-Hepatotoxic, Carbon Tetrachloride, Feronia Limonia Swingle

\section{Introduction}

Feronia limonia Swingle (Syn. Feronia elephantum Correa, Fam Rutaceae) are described in ayurvedic literature as Kapittha is a moderate-sized tree with straight sharp strong spines, $1.2-3.7 \mathrm{~cm}$ long, which is widely distributed throughout Bangladesh, Srilanka, Java and India [1-3]. The fruits of the plant are edible and considered to be a stomachic, astringent, diuretic, cardiotonic and tonic to the liver and lungs [2]; the bark is occasionally used for biliousness [4]; the leaves are aromatic and carminative and are used for the treatment of indigestion and minor bowel infections of children [2]; the roots are sometimes given for the treatment of snake-bites [2]. Previous phytochemical work was mainly focused on the isolation of coumarins [5-7], steroids and volatile components $[8,9]$ of the plant.

Feronia limonia has great reputation in Ayurvedic medicine for treatment of liver disorders. No scientific and methodical investigations have so far been reported in literature regarding its action on liver. Hence the present study is focused to evaluate the hepatoprotective potentials of the Feronia limonia fruits against $\mathrm{CCl}_{4}$ induced liver injury in rats.

\section{Experimental}

\subsection{Plant Collection}

Fruits of Feronia limonia were collected during September-October 2006 from wild area in the vicinity of Allahabad. The fruit of plant was authenticated by Dr. M.P. Sharma, Reader and taxonomist, Department of Botany, Hamdard University, New Delhi. A voucher specimen (No. PD-FP-32) of plant was kept in herbarium of Hamdard University, New Delhi.

\subsection{Preparation of Extract}

Coarsely powdered dry fruits of Feronia limonia $(500 \mathrm{~g})$ were extracted to exhaustively with petroleum ether $\left(60-80^{\circ} \mathrm{C}\right)$, chloroform and methanol using a sohxlet apparatus. The extracts thus obtained were dried under reduce pressure yielding $6.9 \%, 17.4 \%, 31.8 \%$ powder with reference to dry starting material respectively.

\subsection{Experimental Animals}

Male albino rats of wistar strain (150-200 g) were em- 
ployed for assessing the antihepatotoxic activity. They were procured from the Central Animal House of Jamia Hamdard, New Delhi Sanction Letter No. (173/CPCSEA), after approval under the project proposal number-326. They were maintained under controlled condition of light $(12 / 24 \mathrm{~h})$ and temperature $\left(23 \pm 1{ }^{\circ} \mathrm{C}\right)$. Food pellets (Hindustan lever Ltd. Mumbai, India) and tap water were provided ad libitum. For experimental purposes animals were kept fasting but were allowed free access to water.

\section{4. $\mathrm{CCl}_{4}$-Induced Hepatotoxicity}

The animals were divided into six groups of six animals each. Group I served as normal control which received normal saline only. Group II served as $\mathrm{CCl}_{4}$ control and received $\mathrm{CCl}_{4}$ :liquid paraffin $(1: 1,1.5 \mathrm{ml} / \mathrm{kg}$, b.w., p.o.) on first day. Group III served as standard control and received single dose of $\mathrm{CCl}_{4}$ :liquid paraffin $(1: 1,1.5 \mathrm{ml} / \mathrm{kg}$, b.w., p.o.) on first day and thereafter received treatment with standard drug silymarin (Silybon-70) $(10 \mathrm{mg} / \mathrm{kg}$, b.w., p.o.) for 7 days. Groups IV-VI received single dose of $\mathrm{CCl}_{4}$ :liquid paraffin $(1: 1,1.5 \mathrm{ml} / \mathrm{kg}$, b.w., p.o.) on first day and thereafter treated with petroleum, chloroform and methanolic extract of fruits of Feronia limonia (500 mg/kg, b.w., p.o.) [10], respectively, for 7 days.

\subsection{Assessment of Liver Functions}

Rats of all groups were anaesthetized with $1.2 \mathrm{~g} / \mathrm{kg} \mathrm{b.w}$, of a $25 \% \mathrm{w} / \mathrm{v}$ aqueous solution of urethane (Loba-Chemie, Bombay), given on 8th day. The blood collected by puncturing the orbital plexus was allowed to coagulate at ambient temperature for $30 \mathrm{~min}$. and the rats were sacrificed by decapitation. Serum was separated by centrifugation at $3500 \mathrm{rpm}$ for $10 \mathrm{~min}$. The livers of all animals were removed and processed for histological investigations.

In serum, alanine aminotransferase (ALT), aspartate aminotransferase (AST) [11], alkaline phosphatase (ALP) [12], total serum protein (TSP) [13] and bilirubin [14] were measured. Glutathione (GSH) [15], glycogen (GLY) [16] and glutathione peroxidase (GPX) [17] were estimated in liver homogenate.

\subsection{Histological Investigations}

Liver slices fixed for $48 \mathrm{~h}$ in $10 \%$ formosaline were processed for paraffin embedding following the standard microtechnique [18]. Sections $(5 / \sim m)$ of livers stained with haematoxylin and eosin were evaluated for histopathological changes under a light microscope.

\subsection{Statistical Analysis}

The data were expressed as mean \pm S.E.M. $(n=6)$. Re- sults were analyzed statistically by one-way ANOVA followed by Dunnett's test. The difference was considered significant if $\mathrm{p}<0.05$.

\section{Results and Discussion}

\section{1. $\mathrm{CCl}_{4}$ Induced Hepatotoxicity}

It is well established from the earlier studies that the cleavage of carbon-chlorine bond ( $\mathrm{C}-\mathrm{Cl}$ bond) of carbon tetrachloride leads to the formation of trichloromethyl peroxy radical $\left(\mathrm{CCl}_{3} \cdot \mathrm{O}^{2-}\right)$, which is involved in the pathogenesis of liver injury [19].The abnormal higher levels of serum SGPT, SGOT, ALP and bilirubin; and decrease in total protein observed (Table 1) was the consequence of carbon tetrachloride induced liver disfunction and denotes the damage to the hepatic cells [20]. Feeding of Feronia limonia extracts to such carbon tetrachloride-treated rats reduced the enhanced level of serum glutamate oxaloacetate transaminase (SGOT) by $16.74,32.18$, and $42.20 \%$, serum glutamate pyruvate transaminase (SGPT) by $14.46,31.87$ and $34.12 \%$, alkaline phosphatase (ALP) by 20.71, 25.98 and $29.64 \%$ and serum bilirubin by $39.38,40.92,42.19 \%$ which seems to offer the protection and maintain the functional integrity of hepatic cells. Glutathione (GSH) constitutes the first line of defense against free radicals. Reduction in liver GSH and decrease in GPX activity in carbon tetrachloride-treated rats (Table 2) indicated the damage to the hepatic cells, which was confirmed by the earlier reports [20]. Administration of Feronia limonia promoted the conversion of GSSG (oxidised glutathione) into GSH by the reactivation of hepatic glutathione reductase enzyme in carbon tetrachloride-treated animals. The availability of sufficient amount of GSH thus increased the detoxification of active metabolites of carbon tetrachloride through the involvement of GPX. But the restoration of liver glutathione (GSH) by 13.82, 37.50 and $59.04 \%$ and liver glutathione peroxidase (GPX) by 18.71, 21.37and $39.83 \%$ after the enduration of the Feronia limonia extracts to such carbon tetrachloride-treated rats account for the protective efficacy of the extract. Decrease in total serum protein (TSP) (Table 1) and liver glycogen (GLY) (Table 2) observed in the rats treated with carbon tetrachloride may be associated with the decrease in the number of hepatocytes, which in turn may result into the decreased hepatic capacity to synthesize protein and GLY and consequently decrease in the liver weight (Table 2) but when the Feronia limonia extracts were given along with the carbon tetrachloride, the significant increase in the glycogen (GLY) by $31.61,15.92$ and $39.94 \%$, total serum albumin (TSA) by $37.76 \%, 53.64 \%$, $63.51 \%$ and total serum protein (TSP) by $40.83,45.41$ and $50.41 \%$ was observed indicating the antihepatotoxic activity of the extracts and also accounting for the increase 
Table 1. Effect of Feronia limonia extracts on the level of serum SGOT, SGPT, ALP, bilirubin and total protein.

\begin{tabular}{|c|c|c|c|c|c|c|}
\hline Group & SGOT (unit/ml) & SGPT (unit/ml) & ALP (unit/ml) & Total Bilirubin $(\mathrm{g} / \mathrm{dl})$ & Total albumin (g/dl) & Total Protein $(\mathrm{g} / \mathrm{dl})$ \\
\hline Group I (Normal) & $59.49 \pm 2.40^{* *}$ & $48.22 \pm 2.87 * *$ & $47.71 \pm 1.62 * *$ & $2.12 \pm 0.20^{* *}$ & $4.57 \pm 0.28 * *$ & $7.47 \pm 0.32 * *$ \\
\hline Group II $\left(\mathrm{CCl}_{4}\right)$ & $175.54 \pm 3.80$ & $134.94 \pm 5.02$ & $82.06 \pm 2.07$ & $3.91 \pm 0.07$ & $2.33 \pm 0.21$ & $4.80 \pm 0.25$ \\
\hline $\begin{array}{l}\text { Group III } \\
\text { (Silymarin) }\end{array}$ & $\begin{array}{c}95.14 \pm 3.27^{* *} \\
(45.80 \%)\end{array}$ & $\begin{array}{c}76.00 \pm 3.04 * * \\
(43.67 \%)\end{array}$ & $\begin{array}{c}51.45 \pm 1.44^{* *} \\
(37.96 \%)\end{array}$ & $\begin{array}{c}2.23 \pm 0.18^{* *} \\
\quad(42.96 \%)\end{array}$ & $\begin{array}{c}3.58 \pm 0.15^{* *} \\
(53.64 \%)\end{array}$ & $\begin{array}{c}7.44 \pm 0.18^{* *} \\
(55.16 \%)\end{array}$ \\
\hline $\begin{array}{l}\text { Group IV } \\
\text { (Petroleum ether) }\end{array}$ & $\begin{array}{c}146.15 \pm 2.46^{* *} \\
(16.74 \%)\end{array}$ & $\begin{array}{c}115.42 \pm 4.54^{* *} \\
(14.46 \%)\end{array}$ & $\begin{array}{l}65.06 \pm 4.42 * * \\
(20.71 \%)\end{array}$ & $\begin{array}{c}2.39 \pm 0.12^{* *} \\
(39.38 \%)\end{array}$ & $\begin{array}{c}3.21 \pm 0.19^{*} \\
(37.76 \%)\end{array}$ & $\begin{array}{c}6.76 \pm 0.25^{*} \\
(40.83 \%)\end{array}$ \\
\hline $\begin{array}{l}\text { Group V } \\
\text { (Chloroform) }\end{array}$ & $\begin{array}{c}119.05 \pm 2.94^{* *} \\
(32.18 \%)\end{array}$ & $\begin{array}{c}91.93 \pm 2.57 * * \\
(31.87 \%)\end{array}$ & $\begin{array}{c}60.74 \pm 2.36^{* *} \\
(25.98 \%)\end{array}$ & $\begin{array}{c}2.31 \pm 0.18^{* *} \\
(40.92 \%)\end{array}$ & $\begin{array}{c}3.58 \pm 0.14^{* *} \\
(53.64 \%)\end{array}$ & $\begin{array}{c}6.98 \pm 0.21^{* *} \\
(45.41 \%)\end{array}$ \\
\hline $\begin{array}{l}\text { Group VI } \\
\text { (Methanol) }\end{array}$ & $\begin{array}{c}101.45 \pm 2.70^{* * *} \\
\quad(42.20 \%)\end{array}$ & $\begin{array}{c}88.89 \pm 2.91 * * \\
\quad(34.12 \%)\end{array}$ & $\begin{array}{c}57.73 \pm 1.53^{* *} \\
(29.64 \%)\end{array}$ & $\begin{array}{c}2.24 \pm 0.23^{*} \\
(42.19 \%)\end{array}$ & $\begin{array}{c}3.81 \pm 0.17^{* *} \\
(63.51 \%)\end{array}$ & $\begin{array}{c}7.23 \pm 0.17 * * \\
(50.41 \%)\end{array}$ \\
\hline
\end{tabular}

Values are mean \pm S.E. $(n=6)$.

$* \mathrm{P}<0.05$ as compared with Group II., $* * \mathrm{P}<0.01$ as compared with Group II

Table 2. Effect of Feronia limonia extracts on the level of liver GSH, GPX, GLY, body weight (before and after treatment) and liver weight.

\begin{tabular}{|c|c|c|c|c|c|c|}
\hline \multirow{2}{*}{ Group } & \multirow{2}{*}{$\begin{array}{c}\text { GSH } \\
\text { (g/mg protein) }\end{array}$} & \multirow{2}{*}{$\begin{array}{c}\text { GLY } \\
(\mathrm{mg} / \mathrm{gm} \text { of wet tissue) }\end{array}$} & \multirow{2}{*}{$\begin{array}{c}\text { GPX } \\
\text { (micrograms of glutathione } \\
\text { utilized } / \mathrm{min} / \mathrm{mg} \text { protein) }\end{array}$} & \multicolumn{2}{|c|}{ Body weight } & \multirow{2}{*}{$\begin{array}{l}\text { Liver weight } \\
\text { (gm) }\end{array}$} \\
\hline & & & & $\begin{array}{l}\text { Before treatment } \\
(\mathrm{gm})\end{array}$ & $\begin{array}{l}\text { After treatment } \\
(\mathrm{gm})\end{array}$ & \\
\hline Group I (Normal) & $6.15 \pm 0.25^{* *}$ & $28.17 \pm 0.33 * *$ & $7.89 \pm 0.02 * *$ & $160.9 \pm 5$ & $175.1 \pm 4$ & $6.1 \pm 0.4$ \\
\hline Group II (CCl4) & $3.76 \pm 0.19$ & $18.60 \pm 0.20$ & $4.97 \pm 0.06$ & $162.4 \pm 2$ & $168.3 \pm 3$ & $6.08 \pm 0.7$ \\
\hline $\begin{array}{l}\text { Group III } \\
\text { (Silymarin) }\end{array}$ & $\begin{array}{c}6.07 \pm 0.32 * * \\
(61.43 \%)\end{array}$ & $\begin{array}{c}26.99 \pm 0.65 * * \\
(45.10 \%)\end{array}$ & $\begin{array}{l}7.13 \pm 0.34 * * \\
\quad(43.46 \%)\end{array}$ & $170.02 \pm 6$ & $186 \pm 7$ & $5.96 \pm 0.4$ \\
\hline $\begin{array}{l}\text { Group IV } \\
\text { (Petroleum ether) }\end{array}$ & $\begin{array}{c}4.28 \pm 0.27 * \\
\quad(13.82 \%)\end{array}$ & $\begin{array}{c}24.48 \pm 0.28 * * \\
(31.61 \%)\end{array}$ & $\begin{array}{l}5.90 \pm 0.15^{*} \\
\quad(18.71 \%)\end{array}$ & $176 \pm 4$ & $191 \pm 6$ & $6.75 \pm 0.2$ \\
\hline $\begin{array}{l}\text { Group V } \\
\text { (Chloroform) }\end{array}$ & $\begin{array}{l}5.17 \pm 0.32 * \\
(37.50 \%)\end{array}$ & $\begin{array}{c}21.56 \pm 0.38 * * \\
\quad(15.92 \%)\end{array}$ & $\begin{array}{l}6.05 \pm 0.04 * * \\
\quad(21.73 \%)\end{array}$ & $165 \pm 3$ & $178 \pm 5$ & $5.80 \pm 0.4$ \\
\hline $\begin{array}{l}\text { Group VI } \\
\text { (Methanol) }\end{array}$ & $\begin{array}{c}5.98 \pm 0.39 * * \\
(59.04 \%)\end{array}$ & $\begin{array}{c}26.03 \pm 0.37 * * \\
(39.94 \%)\end{array}$ & $\begin{array}{l}6.95 \pm 0.06 * * \\
\quad(39.83 \%)\end{array}$ & $172 \pm 4$ & $188 \pm 6$ & $6.54 \pm 0.6$ \\
\hline
\end{tabular}

Values are mean \pm S.E. $(n=6)$.

$* \mathrm{P}<0.05$ as compared with Group II., ${ }^{* * \mathrm{P}}<0.01$ as compared with Group II

in the liver weight most probably through the hepatic cell regeneration. It was conclusively observed that the methanolic extract exhibited most significant result among all the extracts.

\subsection{Histopathology}

Histomorphology of the livers of the untreated control (Figure l(a)), the $\mathrm{CCl}_{4}$ treated (Figure l(b)) and the petroleum, chloroform, methanolic extract of Feronia li- monia plus toxin treated (Figures $\mathbf{1}(\mathbf{d}, \mathbf{e}, \mathbf{f})$ ) respectively. $\mathrm{CCl}_{4}$ administration caused gross necrosis of the centrilobular hepatocytes characterized by nuclear pyknosis, karyolysis and eosinophilic infiltration (Figure l(b)). Treatment with the extracts of the Feronia limonia reversed, to a large extent, the hepatic lesions produced by $\mathrm{CCl}_{4}$, as is obvious from the absence of eosinophilia and presence of fewer necrotic zones (Figures 1(d, e, f)). Further, the methanolic extract exhibited most significant recovery of hepatic cells, which is in accordance with the results obtained in biochemical parameters. 


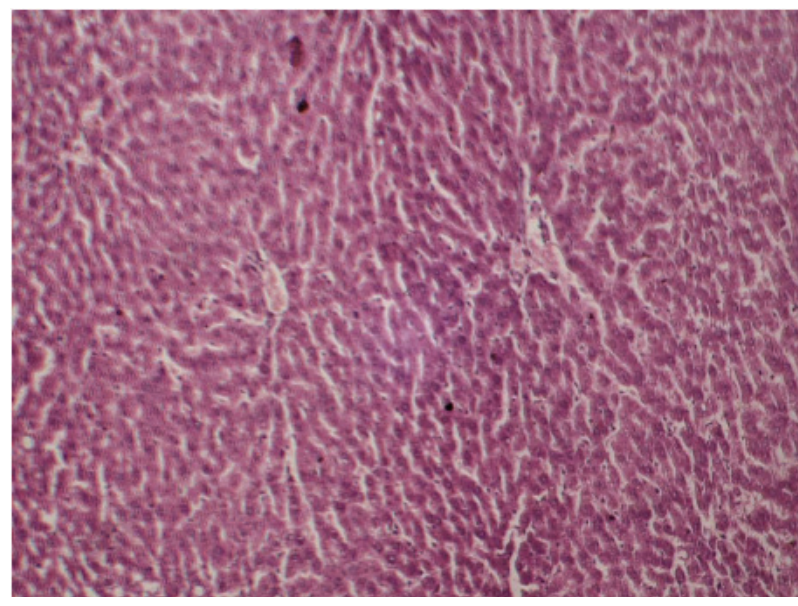

(a)

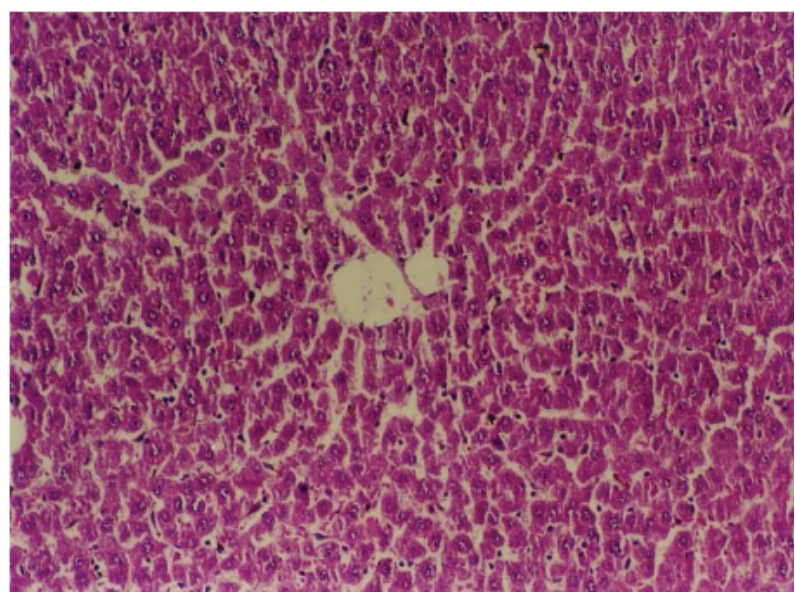

(c)

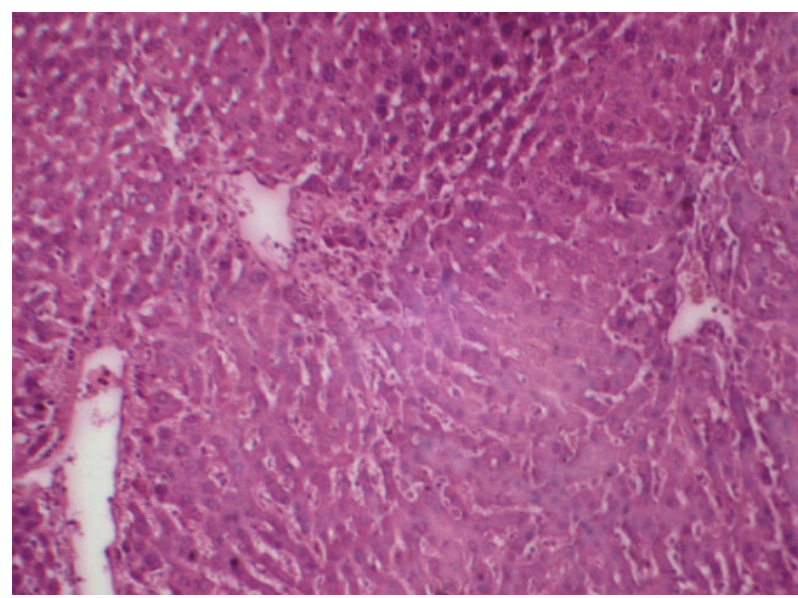

(e)

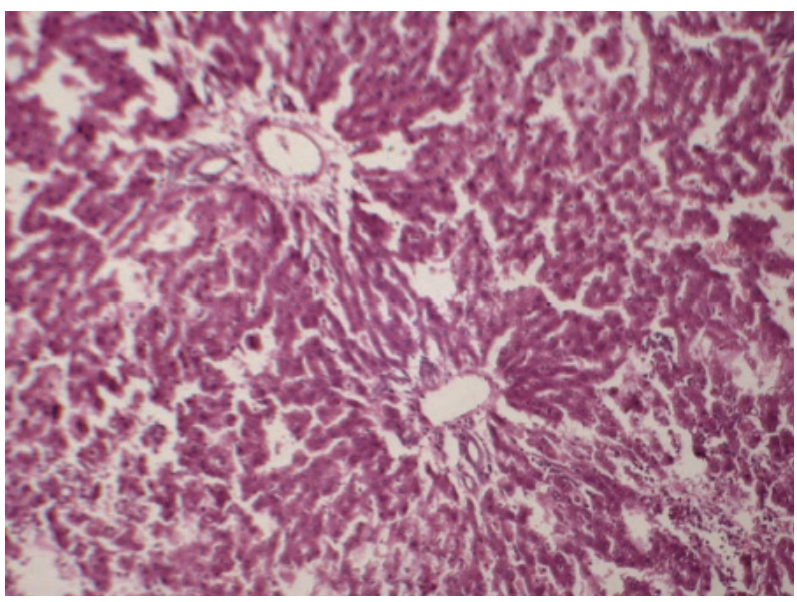

(b)

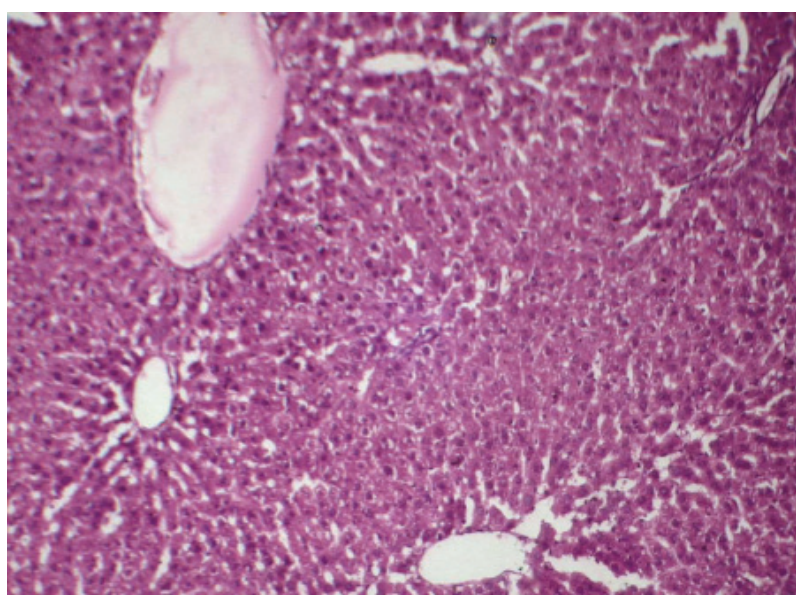

(d)

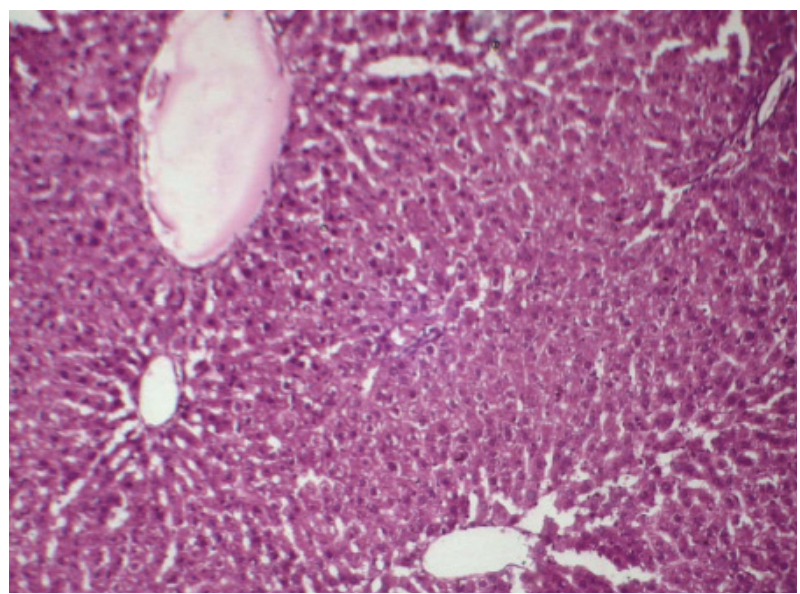

(f)

Figure 1. (a) Histology of the liver of control rat showing normal hepatic cells architecture, (b) Histology of the liver of carbon tetrachloride-treated rats showing necrosis with the obliteration of architecture in hepatic cells, (c) Histology of the liver treated with silymarin showing recovery of the hepatic cells, (d) Histology of the liver treated with petroleum extract of Feronia limonia showing recovery of the hepatic cells, (e) Histology of the liver treated with chloroform extract of Feronia limonia showing recovery of the hepatic cells, (f) Histology of the liver treated with methanol extract of Feronia limonia showing recovery of the hepatic cells. 


\section{Conclusions}

It appears from our results that the mode of action of Feronia limonia fruit extracts in affording the hepatoprotective activity against carbon tetrachloride may be due to the cell membrane stabilization, hepatic cell regeneration and activation of antioxidative enzymes such as glutathione reductase, glutathione peroxidase, superoxide dismutase and catalase.

\section{References}

[1] J. D. Hooker, "The Flora of British India," L. Reeve \& Co, London, 1875, p. 178.

[2] K. R. Kirtikar, B. D. Basu and I. C. S. An, "Indian Medicinal Plants," Orient Enterprises, Dehradun, India, 1993, Vol. 1, pp. 496-498.

[3] M. Yusuf, J. U. Chowdhury, M. A. Wahab and J. Begum, "Medicinal Plants of Bangladesh," BCSIR Laboratories. Chittagong, 1994, pp. 112-114.

[4] L. M. Perry, "Medicinal plants of East and Southern Asia," The MIT Press, Cambridge, 1980, pp. 87-88.

[5] S. K. Talapatra, M. K. Chaudhuri and B. Talapatra, "Coumarins from the Root Bark of Feronia Elephantum," Phytochemistry, Vol. 12, 1973, pp. 236-237.

[6] S. R. Gupta, T. R. Seshadri, C. S. Sharma and N. D. Sharma, "Chemical Components of Feronia Limonia," Planta Medica, Vol. 36, 1979, pp. 95-96.

[7] A. Agrawal, I. R. Siddique and J. Singh, "Coumarins from the Roots of Feronia Limonia," Phytochemistry, Vol. 28, No. 4, 1989, pp. 1229-1232.

[8] A. J. Macleod and N. M. Pieris, "Volatile Flavour Components of Wood Apple (Feronia Limonia) and a Processed Product," Journal of Agricultural and Food Chemistry, Vol. 29, No. 1, 1981, pp. 49-53.

[9] A. Ahmad, L. N. Misra and R. S. Thakur, "Composition of the Volatile Oil from Feronia Limonia Leaves," Planta
Medica, Vol. 55, 1989, pp. 199-200.

[10] B. Ahmed, T. A. Al-Howiriny and A. B. Siddique, Journal of Ethanopharmacology, Vol. 7, 2003, p. 237.

[11] S. Reitman and S. Frankel, "In Vitro Determination of Transaminase Activity in Serum," American Journal of Clinical Pathology, Vol. 28, 1957, p. 56.

[12] P. R. N. Kind and E. J. King, "Estimation of Plasma Phosphatase by Determination of Hydrolysed Phenol with Amino Antipyrine," Journal of Clinical Pathology, Vol. 7, 1954, p. 322.

[13] O. H. Lowry, N. J. Rosebrough, A. L. Farr and R. J. Randall, "Protein Measurement with Folin-Phenol Reagent," Journal of Biological Chemistry, Vol. 193, No. 1, 1951, p. 265.

[14] L. Jendrassik and P. Grof, "Vereinfachte Photo-Metrische Methoden zur Bestimmung des Bilirubins," Biochemische Zeitschrift, Vol. 297, 1938, pp. 81-89.

[15] E. Beutler, O. Duran and B. M. Kelly, "Improved Method for the Determination of Blood Glutathione," Journal of Laboratory Clinical Medicine, Vol. 61, 1963, p. 882.

[16] W. Z. Hassid and S. Abraham, "Chemical Procedures for Analysis of Polysaccarides," In: S. P. Colowick and N. O. Kaplan Eds., Methods in Enzymology, Academic Press Inc., New York, Vol. 3, 1957, p. 34.

[17] J. T. Rotruck, A. L. Pope, H. E. Ganther, D. G. Hafeman and W. G. Hoekstra, "Selenium: Biochemical Role as a Component of Glutathione Peroxidase," Science, Vol. 179, No. 4073, 1973, pp. 588-590.

[18] A. E. Galigher and E. N. Kozloff, "Essentials of Practical Microtechnique," 2nd Edition, Philadelphia, 1971, p. 210.

[19] K. H. Cheeseman, E. F. Albano, A. Thomasi and T. Slater, "Biochemical Studies on the Metabolic Activation of Halogenated Alkanes," Environmental Health Perspectives, Vol. 64, 1985, pp. 85-101.

[20] K. Singh, A. K. Khanna and R. Chandan, "Hepatoprotective Activity of Ellagic Acid against Carbon Tetrachloride Induced Hepatotoxicity in Rats," Indian Journal of Experimental Biology, Vol. 37, No. 10, 1999, pp. 10251026 